\title{
Multi-variable SWAT model calibration with remotely sensed evapotranspiration and observed flow
}

\section{Calibração multi-variável do modelo SWAT com evapotranspiração proveniente de sensoriamento remoto e vazão observada.}

\author{
Ana Clara Lazzari Franco ${ }^{1}$ and Nadia Bernardi Bonumá ${ }^{1}$ \\ ${ }^{1}$ Universidade Federal de Santa Catarina, Florianópolis, SC, Brasil \\ E-mails: anaclaralfranco@gmail.com (ACLF),nadia.bonuma@ufsc.br (NBB)
}

Received: June 28, 2016 - Revised: November 01, 2016 - Accepted: November 21, 2016

\begin{abstract}
Although intrinsic, uncertainty for hydrological model estimation is not always reported. The aim of this study is to evaluate the use of satellite-based evapotranspiration on SWAT model calibration, regarding uncertainty and model performance in streamflow simulation. The SWAT model was calibrated in a monthly step and validated in monthly (streamflow and evapotranspiration) and daily steps (streamflow only). The validation and calibration period covers the years from 2006 to 2009 and the study area is the upper Negro river basin, situated in Santa Catarina and Paraná. SWAT-CUP was used to calibrate and validate the model, using SUFI-2 with KGE (Kling-Gupta Efficiency) as objective function. Different calibration strategies were evaluated, considering single-variable and multi-variable calibration, using streamflow and evapotranspiration. Compared to conventional single-variable calibration (streamflow only), multi-variable calibration (streamflow and evapotranspiration, simultaneously) produce better streamflow performance, especially for low flow periods and daily step validation. Despite that, no evidence of reduction of streamflow prediction uncertainty was observed. SWAT model calibration using solely evapotranspiration still requires further studies.
\end{abstract}

Keywords: Uncertainty; METRIC; SUFI-2; Kling-Gupta Efficiency (KGE).

\section{RESUMO}

Apesar de intrínseca, a incerteza das estimativas de modelos hidrológicos nem sempre é apresentada nos estudos relacionados. O presente trabalho procura avaliar o uso de evapotranspiração proveniente de sensoriamento remoto na calibração do modelo SWAT, em relação às incertezas e desempenho da simulação de vazão. O modelo SWAT foi calibrado em escala mensal e validado em escala mensal (vazão e evapotranspiração) e diária (somente vazão). O período de calibração e validação compreende os anos entre 2006 e 2009 e a área de estudo é a bacia hidrográfica do alto rio Negro, localizada nos estados de Santa Catarina e Paraná. As calibrações e validações foram realizadas no SWAT-CUP, pelo SUFI-2, utilizando como função objetivo o índice KGE (Kling-Gupta Efficiency). Diferentes estratégias de calibração foram avaliadas, considerando o uso individual e simultâneo (multi-variável) da vazão e evapotranspiração. Comparada com a calibração convencional (somente com dados de vazão), a calibração multi-variável (evapotranspiração + vazão) apresentou melhor desempenho da simulação de vazão, especialmente para baixas vazões e para validação em escala diária. Entretanto, a calibração multi-variável não foi capaz de evidenciar diminuição nas incertezas envolvidas nas estimativas de vazão. A calibração do modelo SWAT utilizando somente dados de evapotranspiração ainda depende da realização de mais estudos.

Palavras-chave: Incertezas; METRIC; SUFI-2; Kling-Gupta Efficiency (KGE). 


\section{INTRODUCTION}

Hydrological models are widely used to support water resource management, planning and decision making (DAGGUPATI et al., 2015a). Hydrological models are approximations of the real system, and therefore, unable to consider all processes and variables, causing model uncertainty to be present in its predictions (BEVEN, 2012; MORADKHANI; SOROOSHIAN, 2009).

Besides model uncertainty, the parameters, data input and scale simplifications are also uncertainty sources (ABBOT'T; REFSGAARD, 1996; BEVEN, 2012). Wagener and Gupta (2005) emphasize the need to propagate and clearly relate the model uncertainties, associating an appropriate degree of confidence for the model estimates. A model calibration procedure attempts to reduce uncertainty from model parameters estimation and interpolation, obtaining the best parameterization for the local conditions (ABBOTT'; REFSGAARD, 1996; ARNOLD et al., 2012).

Inverse modelling - IM - denotes the calibration procedure that infers parameter values from model output variable observations (ABBASPOUR, 2005). But one model output variable can be relatively well simulated by several different parameter values, leading to parameter non-uniqueness and equifinality problems (ABBASPOUR, 2005; BEVEN; BINLEY, 1992; BEVEN, 1993).

The use of multi-variable and multi-site calibration in hydrologic distributed models can help reduce equifinality problems, since less parameter sets can satisfy calibration criteria at all sites simultaneously (BEVEN, 2006, 2012; DAGGUPATI et al., 2015b). However, model calibration is commonly performed with watershed outlet streamflow data only. Consequently, part of the processes, specially from the unsaturated zone, can remain uncalibrated (WANDERS et al., 2014).

Remotely sensed evapotranspiration (ET) has important spatial and temporal resolution and can be used to estimate soil water balance related parameters, such as soil moisture (ALLEN et al., 2007; GITHUI; SELLE; THAYALAKUMARAN, 2012; IMMERZEEL; DROOGERS, 2008). Recently, some studies have integrated remote sensing data into the calibration of distributed hydrological models (GITHUI; SELLE; THAYALAKUMARAN, 2012; MUTHUWATTA; BOOIJ; RIENTJES, 2009) obtaining streamflow prediction performance improvement (KUNNATHPOOVAKKA et al., 2016; WANDERS et al., 2014; ZHANG et al., 2009).

Rajib, Merwade and Yu (2016) calibrated the SWAT model using streamflow and soil moisture simultaneously, and compared it with the conventional calibration (streamflow only). Remotely sensed soil moisture and field soil moisture measurements were used. The authors normalized the final calibrated parameter intervals and reported parameter uncertainty reduction when the model was calibrated with both soil moisture and streamflow.

Immerzeel and Droogers (2008) calibrated the SWAT model for a $45,678 \mathrm{~km}^{2}$ Indian basin, using remotely sensed evapotranspiration only. Monthly estimates of evapotranspiration were derived applying SEBAL to MODIS imagery, and the model was compared to available observed streamflow data.

Githui, Selle and Thayalakumaran (2012) also used remotely sensed evapotranspiration, together with streamflow measurements, to calibrate the SWAT model and estimate aquifer recharge for an Australian irrigated basin (irrigation $325 \mathrm{~mm} \mathrm{ano}^{-1}$ ).
The authors related good performance for the SWAT to simulate evapotranspiration, having obtained $\mathrm{R}^{2}$ of 0,87 and low PBIAS values. The study was carried out in an area with low rainfall and evapotranspiration rates (284 mm year ${ }^{-1}$ and $290 \mathrm{~mm}_{\text {year }}{ }^{-1}$ ).

Among commonly used hydrological models nowadays, SWAT (Soil and Water Assessment Tool) has been extensively applied worldwide and in Brazil (ARNOLD et al., 2012). In Brazil, SWAT model was applied to estimate sediment yield (SANTOS; SCUDELARI; RIGHETTO, 2013), best management practices (STRAUCH et al., 2013) and hierarchical calibration (BRIGHENTI; BONUMÁ; CHAFFE, 2016). Bressiani et al. (2015) identified 100 studies using the SWAT model between the years of 1999 and 2015 in Brazil.

SWAT model calibration can be carried out manually or with calibration softwares, such as SWAT-CUP (SWAT Calibration Uncertainty Procedure). The SWAT-CUP was developed to support users on SWAT calibration, and has five different calibrations methods: GLUE (Generalized Likelihood Uncertainty Estimation); ParaSol (Parameter Solution); MCMC (Markov chain Monte Carlo); PSO (Particle Swarm Optimization) e SUFI-2 (Sequential Uncertainty FItting) (ABBASPOUR, 2015).

Multi-objective calibration can be defined as the optimization problem of $\mathrm{F}(\theta)=\left\{f_{1}(\theta), \ldots, f_{\mathrm{m}}(\theta)\right\}$ regarding $\theta$, where $f_{1}(\theta), \ldots, f_{\mathrm{m}}(\theta)$ are $m$ objective functions, individual and independent from each other, to be simultaneously optimized regarding the $\theta$ model parameters (YAPO; GUPTA; SOROOSHIAN, 1998). These multiple objective functions can be measured from different model output variables (multi-variable), or from the same variable at different locations (multi-site) (GUPTA et al., 2009).

Considering the growing availability and use of remotely sensed products, this study aims to investigate the impact of the multi-variable calibration on the uncertainty and performance of the SWAT model streamflow predictions, in a Brazilian rainforest basin. The multi-variable calibration aims to reduce the parameter non-uniqueness problem, by using remotely sensed evapotranspiration and measured streamflow simultaneously. SWAT model calibration solely with evapotranspiration was also evaluated, an approach which is a novelty in Brazilian basins. Parameter temporal scale transfer was explored through daily streamflow validation with monthly calibrated parameters.

\section{STUDY AREA}

The study area was selected according to evapotranspiration data availability. The evapotranspiration estimates are a product of Uda (2016) study, which applied METRIC model to MODIS imagery, covering the entire Iguaçu river basin. Due to processing limitations and data availability, the modeled area was reduced to the upper Negro river basin only. The upper Negro river basin is located in the states of Santa Catarina and Paraná, between $49^{\circ} 55^{\prime} 15^{\prime \prime} \mathrm{W}$ and $48^{\circ} 56^{\prime} 55^{\prime \prime} \mathrm{W}$ longitudes and $25^{\circ} 55^{\prime} 06^{\prime \prime} \mathrm{S}$ and $26^{\circ} 42^{\prime} 16^{\prime}$ 'S latitudes, with a $3,453 \mathrm{~km}^{2}$ drainage area (Figure 1). Altitude varies from 780 meters, at the basin outlet, until 1,591 meters for the highest area. The average altitude is $885 \mathrm{~m}$ and $80 \%$ of the basin area ranges between 780 and $1,215 \mathrm{~m}$.

Economy in this region is strongly based on timber and furniture industry, besides agriculture (THOMÉ et al., 1999). 
According to Köppen classification, region climate is $\mathrm{Cfb}$ : humid temperate climate with average temperature below $18{ }^{\circ} \mathrm{C}$ for the coldest month and below $22^{\circ} \mathrm{C}$ for the hottest month, constantly humid and with no significant precipitation difference between seasons (THOMÉ et al., 1999). The river basin is located in the Atlantic forest, originally covered with Mixed Ombrophylus Forest (Araucaria Forest) and average annual rainfall of $1,522 \mathrm{~mm}$ (FRANCO et al., 2015).

\section{INPUT DATA AND SWAT MODEL}

The SWAT is an hydraulic-hydrologic model, with physically based equations for basin water cycle. The SWAT model was developed to predict the impact of land use and management, and agricultural chemicals, on water and sediment yield (NEITSCH et al., 2011). The spatial discretization is variable and can be user adjusted.

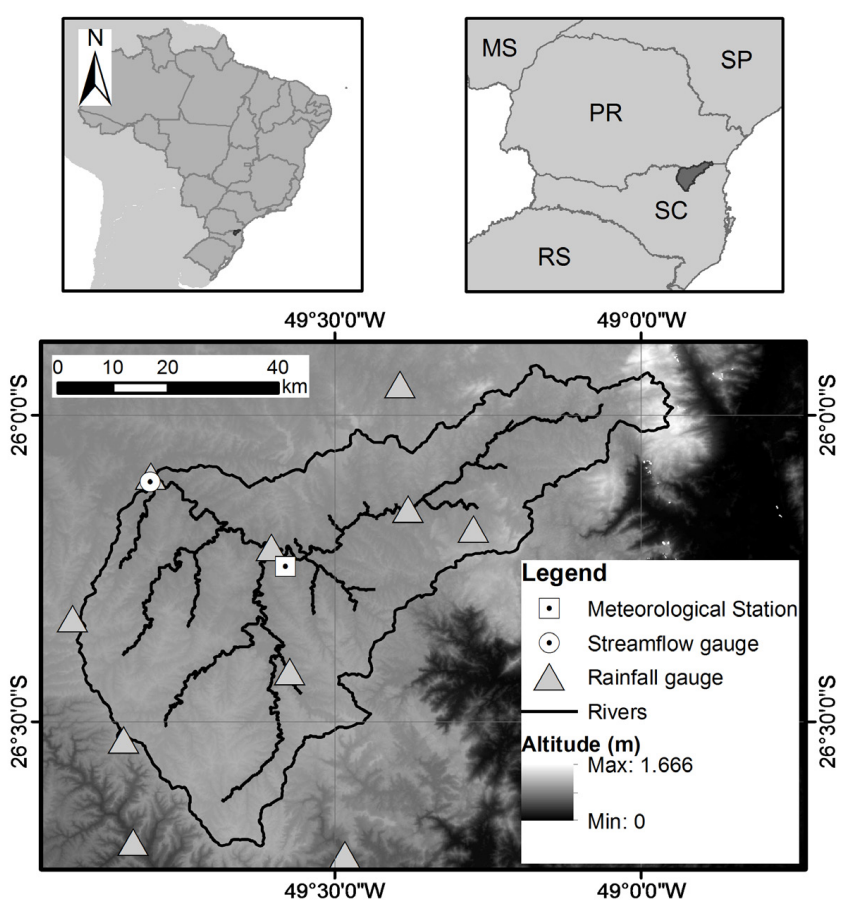

Figure 1. Location of the upper Negro river basin, rainfall and streamflow gauges and meteorologic stations.
The default mode is semi-distributed, using HRUs (Hydrologic Response Units) as simulation units.

Daily precipitation and streamflow data were obtained from the National Water Agency (ANA) online database (ANA, 2016). Meteorological data were obtained from EPAGRI (Santa Catarina State Agricultural Research and Rural Extension Agency) and INMET (National Meteorology Institute), for the Rio Negrinho station. SWAT meteorological input data includes maximum and minimum temperature, solar radiation, wind speed and relative humidity. Data interval comprehends the years from 2004 to 2009, covering model warm-up, calibration and validation. Stations are summarized on Table 1.

Digital Elevation Model (DEM) was obtained from the online EMBRAPA database (EMBRAPA, 2016a) with $90 \mathrm{~m}$ spatial resolution. The DEM is a result of SRTM (Shuttle Radar Topography Mission) data processing (MIRANDA, 2005). The minimum contribution area for stream generation was established in $30 \mathrm{~km}^{2}$ and 66 subbasins were generated on SWAT, according to the basin topography.

The soil type map was build up from the Brazil (SANTOS et al., 2011), Santa Catarina (FASOLO et al., 2004) and Paraná (SANTOS et al., 2009) soil type maps. The soil type maps were downloaded from the online EMBRAPA database (EMBRAPA, 2016b). Information regarding profile samples for each soil type were collected from the EMBRAPA soils database (EMBRAPA, 2016c), which gathers soil profiles information for the entire Brazilian territory. The main soil types are Cambissolos (70.2\%), Nitossolos (11.5\%), Argissolos Vermelho-Amarelo (5.9\%), Neossolos (5.4\%), Latossolos (3.5\%), Organossolos (0.4\%) and Gleissolos $(0.6 \%)$, and rocky outcrops in upstream (headwaters) areas.

\section{Land use and land cover}

The land use and land cover database were produced from Landsat 8 imagery, with $30 \mathrm{~m}$ spatial resolution. Two scenes (220-078 e 221-078) from the year 2014 (26/08/2014 and $07 / 12 / 2014)$ covered the entire basin area. The maps were produced on Spring 5.2.6, using region growing segmentation followed by supervised classification. Image segmentation methods group adjacent pixels to "seed" pixels which aggregate pixels and regions according to some heterogeneity criteria (MENESES; ALMEIDA, 2012). Land use classes were: water, reforestation,

Table 1. Rainfall (P), streamflow (F) and meteorological (M) stations.

\begin{tabular}{|c|c|c|c|c|c|c|c|}
\hline Code & Name & Available data from & Latitude & Longitude & $\begin{array}{l}\text { Altitude } \\
\text { (m) }\end{array}$ & Responsable & Type \\
\hline 2549003 & Rio da Várzea dos Lima & $1 / 9 / 1940$ & -26.0 & -49.4 & 810 & ANA & $\mathrm{P}$ \\
\hline 2649006 & Rio Negro & $1 / 12 / 1922$ & -26.1 & -49.8 & 770 & ANA & $\mathrm{P}$ \\
\hline 2649017 & Doutor Pedrinho & $1 / 12 / 1953$ & -26.7 & -49.5 & 250 & ANA & $\mathrm{P}$ \\
\hline 2649018 & Fragosos & $1 / 05 / 1967$ & -26.2 & -49.4 & 790 & ANA & $\mathrm{P}$ \\
\hline 2649054 & Moema & $1 / 07 / 1976$ & -26.5 & -49.8 & 950 & ANA & $\mathrm{P}$ \\
\hline 2649055 & Corredeira & $1 / 07 / 1976$ & -26.4 & -49.6 & 750 & ANA & $\mathrm{P}$ \\
\hline 2649056 & Itaiópolis & $1 / 07 / 1976$ & -26.3 & -49.9 & 990 & ANA & $\mathrm{P}$ \\
\hline 2649057 & Campo Alegre & $1 / 07 / 1976$ & -26.2 & -49.3 & 870 & ANA & $\mathrm{P}$ \\
\hline 2649058 & Barra do Prata & $1 / 11 / 1977$ & -26.7 & -49.8 & 450 & ANA & $\mathrm{P}$ \\
\hline 65100000 & Rio Negro & $1 / 05 / 1930$ & -26.1 & -49.8 & 766 & COPEL & $\mathrm{F}$ \\
\hline 86945 & Rio Negrinho & $1 / 06 / 1990$ & -26.2 & -49.6 & 857 & EPAGRI/INMET & M \\
\hline
\end{tabular}


native forest, agriculture, exposed soil, urban area and pasture. Exposed soil was later reclassified as also agriculture. Land use and land cover were resampled to $90 \mathrm{~m}$, in order to be compatible with the DEM resolution.

Native forest still covers most of the basin area (49.7\%), especially on the basin headwater and riparian forests. Agriculture is the dominant activity, occupying $26.9 \%$ of the basin area, followed by reforestation (17.7\%). Reforestation is mostly of Pinus elliotti, which supplies local cellulose industry. Urban area and pasture cover approximately $5 \%$ of the basin area, each. Table 2 sumarizes areas and percentuals for each land use and land cover for the upper Negro river basin.

\section{Evapotranspiration}

Potential evapotranspiration (PET) can be directly informed to SWAT, or calculated from meteorological data. The SWAT model provides three methods for PET estimates: Hargreaves, Priestley-Taylor and Penman-Monteith (NEITSCH et al., 2011). For the present study, PET was estimated with Penman-Monteith method.

The actual evapotranspiration is then estimated from the available water capacity and water canopy storage. First, water stored on the vegetation canopy is evaporated. If potential evapotranspiration is higher than the canopy stored volume, the remaining evaporative demand is distributed between plants and soil. The plants transpiration demand is supplied according to the soil available water (NEITSCH et al., 2011).

In the present study, monthly actual evapotranspiration estimates from METRIC application to MODIS imagery, from Uda (2016), were used for model calibration and validation. The author produced estimates of monthly actual evapotranspiration for the years 2006, 2007 and 2009, with $250 \mathrm{~m}$ spatial resolution, for the entire Iguaçu river basin. The average pixel value for each subbasin was used for model calibration and validation.

Evapotranspiration estimates from SEBAL and METRIC present good confidence for monthly scale. Typical accuracy for single-day events and scales of the order of 100 ha is $+/-15 \%$ (BASTIAANSSEN et al., 2005). Also according to Bastiaanssen et al. (2005), typical SEBAL accuracy for one day is $85 \%$, reaching $95 \%$ on seasonal scale and an average value of $96 \%$ for annual scale on large basins. The SUFI-2 calibration algorithm allows the user to inform the percentual measurement error for the observed data used for calibration. For the present study, the value of $10 \%$, suggested by Abbaspour (2015), for typical streamflow measurement conditions, was used for streamflow and evapotranspiration.

Table 2. Land use and land cover for the upper Negro river basin.

\begin{tabular}{|c|c|c|c|}
\hline \multirow{2}{*}{ Class } & \multicolumn{2}{|c|}{ Area } & \multirow{2}{*}{$\frac{\text { SWAT }}{\text { code }}$} \\
\hline & $\mathrm{Km}^{2}$ & $\%$ & \\
\hline Water & 14.2 & 0.4 & WATR \\
\hline Urban & 96.8 & 2.8 & URHD \\
\hline Reforestation & 610.0 & 17.7 & PINE \\
\hline Native Forest & $1,713.8$ & 49.7 & FRST \\
\hline Agriculture & 926.5 & 26.9 & AGRL \\
\hline Pasture & 87.4 & 2.5 & PAST \\
\hline
\end{tabular}

\section{CALIBRATION AND VALIDATION}

Model validation is the procedure in which the calibrated model is executed and evaluated for a different time interval or subbasin. The objective is to compare the model estimates with observed data that were not used on the calibration process, and demonstrate that the model is able to make sufficiently accurate estimates (ARNOLD et al., 2012).

Presented by Klemeš (1986), the split-sample test is a model calibration and validation approach that consists on equally splitting the available data, when the record is sufficiently long to represent different climate conditions. Further discussions on record data length for calibration and validation can be found on Her and Chaubey (2015). When the available record is not sufficient for the $50 / 50$ split, it must be split in two different ways, for example, $70 / 30$ and $30 / 70$, such that the calibration interval is sufficiently long.

The SWAT model was calibrated on monthly time step and validated on monthly time step (for evapotranspiration and streamflow) and daily time step (streamflow only), using SUFI-2. Among the calibration techniques available in SWAT-CUP, SUFI-2 is the one that needs the smallest number of runs to achieve good prediction uncertainty ranges with reasonable coverage of data points (YANG et al., 2008).

The SUFI-2 operates with successive iterations, with the same number of simulations each. For each iteration, the calibrated parameters values interval (Range_Par) are reduced, always centered on the parameter set that produced the best objective function value (Best_Par) (ABBASPOUR, 2015). The iteration number and the number of simulations for each iteration are user defined. The objective function used to define the best parameter values set (Best_Par) is also defined by the user.

In SUFI-2, the uncertainty is expressed as an uniform probability distribution. The uncertainty is indicated by the interval of $95 \%$ probability (95PPU), calculated for the 2.5 and 97.5 percentiles for the accumulated probability distribution of the output variable of interest. This uncertainty is presented as an "envelop" of solutions generated by the parameter value interval used.

To quantify the adjust of the parameter values interval, two statistical indicators are used: the $\mathrm{p}$-factor and the $\mathrm{r}$-factor. The $\mathrm{p}$-factor indicates the percentage of observed data bracket by the 95PPU envelope. The $r$-factor is the uncertainty indicator and it is calculated as the ratio of the average distance between the 2.5 and 97.5 percentiles and the standard deviation of the measured data. The r-factor represents the thickness of the envelope of solutions (95PPU) (ABBASPOUR; JOHNSON; VAN GENUCHTEN, 2004).

A sensitivity analysis were carried out to reduce the number of calibrated parameters. From the sensitivity analysis, 11 parameters were selected to further calibration. The calibrated parameters and initial intervals are summarized on Table 3.

Several statistical performance indicators for streamflow simulation exist. The most commonly reported for SWAT streamflow calibration and validation are the coefficient of determination ( $\mathrm{R}^{2}$, Equation 1), the Nash-Sutcliffe coefficient (NS, Equation 2) and the percent bias (PBIAS, Equation 3). The $\mathrm{R}^{2}$ varies from 0 to 1 , NS varies between $-\infty$ and 1 , and 1 is the optimal value for both. For PBIAS, the value of zero indicates 
Table 3. Calibrated parameters and initial range.

\begin{tabular}{|c|c|c|}
\hline Parameter & Minimum & Maximum \\
\hline CN2 (relative) & -0.25 & 0.25 \\
\hline SOL_AWC (relative) ${ }^{*}$ & -0.25 & 0.25 \\
\hline SOL_K (relative) ${ }^{*}$ & -0.25 & 0.25 \\
\hline ALPHA_BF & 0 & 1 \\
\hline GW_DELAY & 0 & 500 \\
\hline GWQMN & 0 & 5000 \\
\hline LAT_TTIME & 1 & 180 \\
\hline CH_K1 & 1 & 300 \\
\hline CH_N1 & 0.01 & 0.5 \\
\hline RCHRG_DP & 0 & 1 \\
\hline SURLAG & 1 & 24 \\
\hline
\end{tabular}

*The existing parameter value is multiplied by $(1+$ a given value). Parameter definitions and further details can be found in Neitsch et al. (2011).

absence of sub- and super- estimate tendency (ARNOLD et al., 2012; GREEN; VANGRIENSVEN, 2008). These indicators are calculated according to:

$$
\begin{aligned}
& R^{2}=\frac{\left(\sum_{i=1}^{n}\left(O_{i}-\bar{S}\right)\left(S_{i}-\bar{S}\right)\right)^{2}}{\sum_{i=1}^{n}\left(O_{i}-\bar{O}\right)^{2} \sum_{i=1}^{n}\left(S_{i}-\bar{S}\right)^{2}} \\
& N S=1-\frac{\sum_{i=1}^{n}\left(O_{i}-S_{i}\right)^{2}}{\sum_{i=1}^{n}\left(O_{i}-\bar{O}\right)^{2}} \\
& \text { PBIAS }=100\left(\frac{\sum_{i=1}^{n}\left(O_{i}-S_{i}\right)}{\sum O_{i}}\right)
\end{aligned}
$$

where, $n$ is the number of observations for the simulated period, $O i$ and $S i$ are the observed and simulated values for each time step $i, \bar{O}$ and $\bar{S}$ are the observed and simulated average values (GREEN; VANGRIENSVEN, 2008).

According to Abbaspour, Johnson and Van Genuchten (2004) a model is to be considered satisfactory calibrated by SUFI-2 when $\mathrm{R}^{2}$ is higher than 0.80 . Abbaspour (2015) suggests values of p-factor above 0.70 and r-factor below 1.50, for acceptable streamflow calibration. Moriasi et al. (2007) defines NSE $>0.5$ and PBIAS $<+/-25 \%$ as satisfactory values, while NSE $>0.75$ and PBIAS $<+/-10 \%$ are considered very good for streamflow calibration of hydrological models.

The objective function used for model calibration influences the calibration result and final calibrated model performance. Gupta et al. (2009) presented the KGE function (Kling-Gupta Efficiency), based on the decomposition of NS and mean squared error (MSE). The KGE can be decomposed in three terms, which represent the correlation, bias and relative variability between observed and simulated values. The optimal point is computed for a three-dimensional pareto surface, in terms of minimum Euclidian Distance from the ideal point, according to:

$$
K G E=1-E D
$$

with,

$$
E D=\sqrt{(r-1)^{2}+(\beta-1)^{2}+(\alpha-1)^{2}}
$$

$$
\begin{gathered}
\alpha=\frac{\bar{S}}{\bar{O}} \\
\beta=\frac{\sigma_{s}}{\sigma_{o}}
\end{gathered}
$$

where, $E D$ is the Euclidian distance from the ideal point, $r$ is the coefficient of linear correlation between observed and simulated values and $\sigma_{o}$ and $\sigma_{s}$ the standard deviation of observed and simulated values. Similar to NS, KGE values range from $-\infty$ to 1 , and the optimal value is 1 . In case of multiple observed variables, the objective function is defined as:

objective function $=\sum_{j} w_{j} \cdot K G E_{j}$

where, $w_{j}$ is the weight of the variable $j$.

The KGE was used as objective function to allow the simultaneously use of evapotranspiration and streamflow on calibration, and to enable comparison between different strategies. For iterations in which the streamflow and evapotranspiration were used simultaneously, the weight $\left(w_{j}\right)$ of 0.5 was attributed to the outlet streamflow and $0.5 / 66$ to the evapotranspiration of each one of the 66 subbasins.

SWAT model was calibrated and validated using data for the time interval from 2006 to 2009. According to the Split-Sample Test, proposed by Klemeš (1986), the time interval was split unequally, such that the calibration period was sufficiently long, and the remaining data was used for model validation. Therefore, the 4 year interval was split in 3 years for calibration and 1 year for validation, having two years of monthly evapotranspiration estimates for model calibration and one year for the model validation.

Because the SUFI-2 operates with successive independent iterations, the objective function can be distinct for each iteration for the same calibration. Different calibration strategies were evaluated. The strategies consist of two iterations, with 500 simulations each, except for the S3' strategy, which refers to the result of only one iteration. Strategy S1 is the conventional calibration, using outlet streamflow data only, on both iterations. Calibration using solely evapotranspiration data was carried out in two successive iterations. Results for the first iteration are indicated on strategy S3', while the S3 strategy refers to the second iteration. The multi-variable calibration, strategy S2, was carried out using only evapotranspiration data on the first iteration and streamflow and evapotranspiration, simultaneously, for the second iteration.

Figure 2 illustrates the calibration sequence of each strategy, according to the variable considered in the objective function of each iteration. All calibration strategies were compared to each other and with the initial performance of the uncalibrated model (S0). The uncalibrated model refers to the use of default parameters, indicated by the model developers on SWAT manual (NEITSCH et al., 2011).

Evapotranspiration was analyzed only on monthly scale due to the data availability, and streamflow was validated on monthly and daily time steps. Streamflow validation for the daily time step was performed for the entire data interval (from 2006 to 2009), using the monthly calibrated parameters. For the monthly time step, the model was validated according the Split Sample Test, with data that was not used on calibration. 
Although used sometimes, the best parameter set, found during calibration with SUFI-2, should not be used nor propagated for model validation. Abbaspour, Johnson and van Genuchten (2004) point out that calibration with SUFI-2 algorithm aims to find an optimum interval of values for each calibrated parameter (Range_Par), and not to establish a best value for each calibrated parameter (Best_Par). The calibrated parameter intervals (Range_Par) must be able to simulate the output variable of interest with acceptable uncertainty. Model validation, therefore, must be carried out propagating the final calibrated parameter intervals (Range_Par), obtained from the last iteration of the calibration process. With the purpose of exemplifying possible problems from an inadequate approach, the correct model validation, that is, validation using the parameter values interval (Range_Par), will be compared to the use of the best parameter values (Best_Par).

\section{RESULTS AND DISCUSSION}

\section{Initial model performance}

Uncalibrated model performance (S0) for streamflow simulation, on monthly time step, can be considered acceptable only for the 2009 year $(\mathrm{KGE}=0.67, \mathrm{NSE}=0.74$ and $\mathrm{PBIAS}=-3.7 \%)$. Monthly evapotranspiration simulation also exhibits its best performance for the 2009 year, with $\mathrm{KGE}=0.60$, PBIAS $=33.6 \%$ and $\mathrm{R}^{2}=0.81$. Daily uncalibrated model performance is unsatisfactory for all periods, emphasizing the need for model calibration. Streamflow and evapotranspiration statistical performance indicators for the uncalibrated model (S0) are summarized on Table 4.

\section{Calibration and validation strategies}

Daily time step model validation results are presented on Table 5, and monthly time step calibration and validation results are on Table 6. The S3' calibration strategy exhibits model performance superior to the uncalibrated model (S0) for the evapotranspiration and streamflow simulation, in calibration and validation periods. The S3' strategy reached satisfactory performance for daily streamflow, with $\mathrm{p}$-factor between 0.69 and 0.71 , and $\mathrm{r}$-factor from 1.00 to 1.08 . For S3', monthly streamflow also reaches satisfactory performance on calibration(validation) of 2007-2009(2009) with a $\mathrm{p}$-factor of $0.81(0.75)$ and $\mathrm{r}$-factor of 1.15(0.95).

Despite S3's unacceptable $\mathrm{p}$ and $\mathrm{r}$ factors, monthly and daily evapotranspiration and streamflow performance are superior to the uncalibrated model (S0). Still, monthly hydrographs show the S3 tendency to "flatten" the flow peaks (Figure 3 and Figure 4). Compared to S3', the S3 streamflow simulation performance is worst. Calibrated parameters comprehend several hydraulic

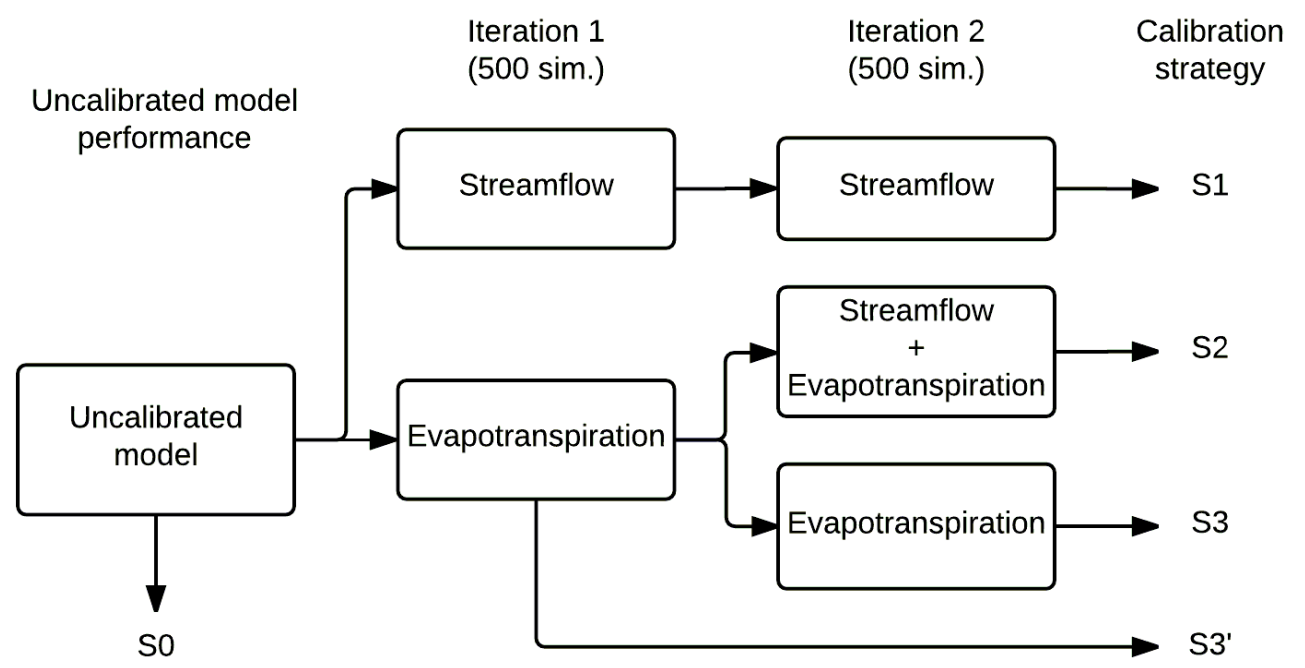

Figure 2. Calibration strategies, according the variable considered for the objective function of each iteration.

Table 4. Performance indicators for the uncalibrated model (S0).

\begin{tabular}{|c|c|c|c|c|c|c|c|c|c|}
\hline \multirow{2}{*}{$\begin{array}{c}\text { Time } \\
\text { interval }\end{array}$} & \multirow{2}{*}{ Variable } & \multicolumn{4}{|c|}{ Monthly time step } & \multicolumn{4}{|c|}{ Daily time step } \\
\hline & & $\mathbf{R}^{2}$ & NS & PBIAS & KGE & $\mathbf{R}^{2}$ & NS & PBIAS & KGE \\
\hline \multirow{2}{*}{ 2006-2008 } & Q & 0.68 & 0.32 & -40.0 & 0.55 & 0.14 & -4.52 & -58.2 & -0.66 \\
\hline & ET & 0.52 & & 40.9 & 0.43 & & & & \\
\hline \multirow{2}{*}{ 2007-2009 } & Q & 0.67 & 0.04 & -43.9 & 0.47 & 0.01 & -3.03 & -18.8 & -0.24 \\
\hline & ET & 0.61 & & 43.5 & 0.44 & & & & \\
\hline \multirow{2}{*}{2006} & Q & 0.76 & -8.40 & -67.1 & -1.29 & 0.17 & -24.31 & -66.1 & -3.25 \\
\hline & ET & 0.37 & & 44.7 & 0.29 & & & & \\
\hline \multirow{2}{*}{2009} & Q & 0.78 & 0.74 & -3.7 & 0.67 & 0.01 & -0.76 & 43.4 & 0 \\
\hline & ET & 0.81 & & 33.6 & 0.60 & & & & \\
\hline
\end{tabular}

$\mathrm{Q}=$ Streamflow; ET=Evapotranspiration; R2=coefficient of determination; NS= Nash-Sutcliffe coefficient; PBIAS=percent bias; KGE=Kling-Gupta Efficience; Satisfactory $\mathrm{p}$ and $\mathrm{r}$ factor values are indicated in bold. 
Table 5. Daily streamflow validation for the time interval of 2006 to 2009.

\begin{tabular}{|c|c|c|c|c|c|c|c|c|c|c|c|}
\hline $\begin{array}{c}\text { Calibration } \\
\text { Strategy }\end{array}$ & $\begin{array}{c}\text { Calibration } \\
\text { period }\end{array}$ & $\mathrm{p}$-factor & r-factor & $\mathbf{R}^{2}$ & NS & PBIAS & KGE & $\bar{S}$ & $\sigma_{s}$ & $(\bar{o})$ & $\left(\sigma_{o}\right)$ \\
\hline \multirow{2}{*}{ S1 } & $2006-2008$ & 0.67 & 0.93 & 0.21 & -0.34 & 2.7 & 0.42 & 59 & 69 & \multirow{8}{*}{$(60)$} & \multirow{8}{*}{ (57) } \\
\hline & 2007-2009 & 0.86 & 1.11 & 0.57 & 0.49 & -4.1 & 0.75 & 63 & 58 & & \\
\hline \multirow{2}{*}{ S2 } & 2006-2008 & 0.96 & 1.27 & 0.67 & 0.65 & 1.9 & 0.80 & 59 & 53 & & \\
\hline & 2007-2009 & 0.96 & 1.24 & 0.66 & 0.65 & 1.9 & 0.80 & 59 & 53 & & \\
\hline \multirow{2}{*}{ S3 } & 2006-2008 & 0.32 & 0.70 & 0.59 & 0.53 & -19.3 & 0.52 & 72 & 35 & & \\
\hline & 2007-2009 & 0.36 & 0.74 & 0.59 & 0.54 & -14.7 & 0.52 & 69 & 35 & & \\
\hline \multirow{2}{*}{ S3' } & $2006-2008$ & 0.69 & 1.08 & 0.69 & 0.67 & -12.7 & 0.77 & 68 & 52 & & \\
\hline & $2007-2009$ & 0.71 & 1.00 & 0.70 & 0.67 & -13.0 & 0.78 & 68 & 53 & & \\
\hline
\end{tabular}

$\mathrm{R} 2=$ coefficient of determination; NS= Nash-Sutcliffe coefficient; PBIAS=percent bias; KGE=Kling-Gupta Efficience; $\bar{s}$ e $\bar{o}=$ average simulated and measured streamflow. $\sigma_{\mathrm{s}}$ e $\sigma_{\mathrm{o}}=$ simulated and measured standard deviation. Satisfactory $\mathrm{p}$ and $\mathrm{r}$ factor values are indicated in bold.

Table 6. Uncertainty and performance indicators for all strategies. Monthly simulation.

\begin{tabular}{|c|c|c|c|c|c|c|c|c|c|}
\hline $\begin{array}{c}\text { Calibration } \\
\text { Strategy }\end{array}$ & $\begin{array}{c}\text { Calibration } \\
\text { Period }\end{array}$ & $\begin{array}{l}\text { (Validation } \\
\text { Period) }\end{array}$ & Variable & p-factor & r-factor & $\mathbf{R}^{2}$ & NS & PBIAS & KGE \\
\hline \multirow{6}{*}{ S1 } & $2007-2009$ & $(2006)$ & Q & $0.94(0.75)$ & $1.27(3.42)$ & $0.78(0.75)$ & $0.78(0.66)$ & $-2.9(-8.9)$ & $0.84(0.84)$ \\
\hline & & & ET & $0.01(0.01)$ & $0.24(0.29)$ & $0.58(0.36)$ & & $46.4(47.1)$ & $0.40(0.26)$ \\
\hline & & & Average & & & & & & $0.62(0.55)$ \\
\hline & $2006-2008$ & (2009) & Q & $0.89(0.92)$ & $1.08(0.75)$ & $0.76(0.58)$ & $0.73(0.58)$ & $0.1(0)$ & $0.87(0.63)$ \\
\hline & & & ET & $0.01(0.02)$ & $0.24(0.23)$ & $0.48(0.77)$ & & $46.5(39.4)$ & $0.35(0.52)$ \\
\hline & & & Average & & & & & & $0.61(0.57)$ \\
\hline \multirow{6}{*}{ S2 } & $2007-2009$ & (2006) & Q & 1(1) & $1.60(4.83)$ & $0.79(0.88)$ & $0.78(0.80)$ & $-2.3(-9.1)$ & $0.89(0.87)$ \\
\hline & & & ET & $0.02(0.04)$ & $0.11(0.12)$ & $0.63(0.39)$ & & $41.3(40.6)$ & $0.48(0.34)$ \\
\hline & & & Average & & & & & & $0.68(0.61)$ \\
\hline & $2006-2008$ & (2009) & $Q$ & $1(1)$ & $1.77(1.15)$ & $0.76(0.89)$ & $0.76(0.82)$ & $5.6(-14.0)$ & $0.83(0.80)$ \\
\hline & & & ET & $0.02(0.03)$ & $0.11(0.11)$ & $0.51(0.81)$ & & $41.9(34.5)$ & $0.41(0.59)$ \\
\hline & & & Average & & & & & & $0.62(0.69)$ \\
\hline \multirow{6}{*}{ S3' } & $2007-2009$ & (2006) & Q & $\mathbf{0 . 8 1}(0.50)$ & $1.15(4.63)$ & $0.85(0.84)$ & $0.84(0.64)$ & $1.5(-7.7)$ & $0.83(0.67)$ \\
\hline & & & ET & $0.02(0.04)$ & $0.17(0.19)$ & $0.63(0.39)$ & & $40.3(41.4)$ & $0.49(0.33)$ \\
\hline & & & Average & & & & & & $0.66(0.50)$ \\
\hline & $2006-2008$ & $(2009)$ & Q & $0.69(\mathbf{0 . 7 5})$ & $1.36(0.95)$ & $0.80(0.93)$ & $0.73(0.90)$ & $-13.9(-11.9)$ & $0.82(0.87)$ \\
\hline & & & ET & $0.02(0.03)$ & $0.18(0.17)$ & $0.50(0.80)$ & & $43.1(35.9)$ & $0.40(0.57)$ \\
\hline & & & Average & & & & & & $0.61(0.72)$ \\
\hline \multirow{6}{*}{ S3 } & $2007-2009$ & (2006) & Q & $0.42(0.33)$ & $0.86(3.68)$ & $0.65(0.52)$ & $0.45(-4.10)$ & $-27.8(-73.3)$ & $0.53(0.21)$ \\
\hline & & & ET & $0.02(0.04)$ & $0.13(0.15)$ & $0.65(0.40)$ & & $37.6(38.6)$ & $0.53(0.37)$ \\
\hline & & & Average & & & & & & $0.53(0.29)$ \\
\hline & 2006-2008 & (2009) & Q & $0.31(0.25)$ & $0.96(0.68)$ & $0.63(0.80)$ & $0.56(0.74)$ & $-17.3(-8.9)$ & $0.60(0.65)$ \\
\hline & & & ET & $0.02(0.03)$ & $0.14(0.13)$ & $0.51(0.82)$ & & $41.3(33.0)$ & $0.42(0.61)$ \\
\hline & & & Average & & & & & & $0.51(0.63)$ \\
\hline
\end{tabular}

$\mathrm{Q}=$ Streamflow; ET=Evapotranspiration; R2=coefficient of determination; NS= Nash-Sutcliffe coefficient; PBIAS=percent bias; KGE=Kling-Gupta Efficience; Satisfactory $\mathrm{p}$ and $\mathrm{r}$ factor values are indicated in bold.

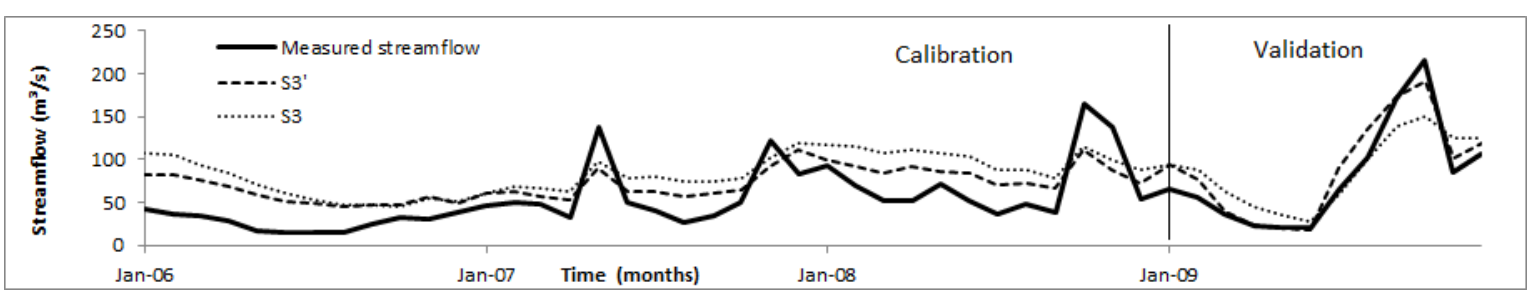

Figure 3. Monthly streamflow calibration (2006-2008) and validation (2009) for strategies S3' and S3.

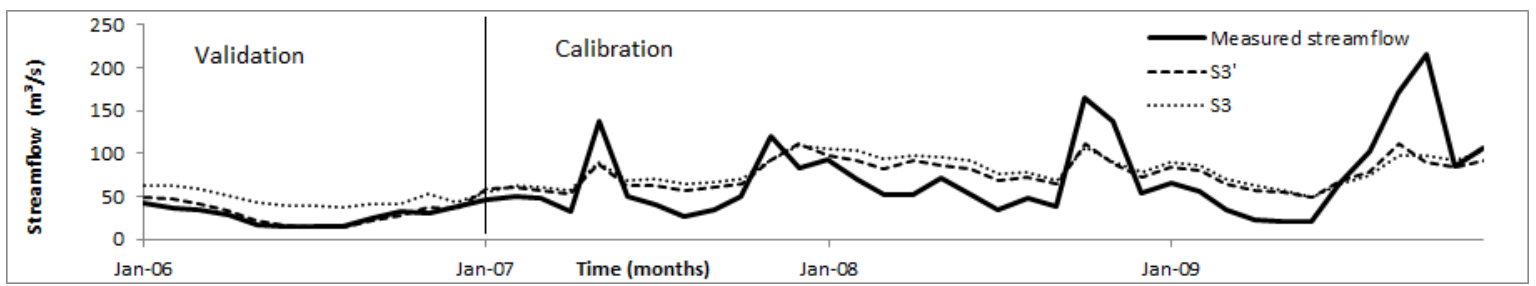

Figure 4. Monthly streamflow calibration (2007-2009) and validation (2006) for strategies S3' and S3. 
channel routing parameters (for example, $\mathrm{CH} \_\mathrm{K} 1$ and $\mathrm{CH} \_\mathrm{N} 1$ ). Calibrating these hydraulic parameters with evapotranspiration data only can cause depreciation on the streamflow simulation performance, observed from S3' to S3.

Objective function (KGE) exhibits the highest values for streamflow alone, and also for the evapotranspiration and streamflow average, on S2 strategy. But, compared to the conventional calibration (S1) for monthly streamflow, S2's higher $\mathrm{p}$ and $\mathrm{r}$ factors indicate higher uncertainty.

For the calibration with data from the interval of 2006 to 2008, S2 was the only strategy able to satisfactory validate the daily streamflow. Figure 5 shows the daily streamflow validation for the interval of July to December of 2009, calibrated by S1 and S2, with monthly data from 2006 to 2008. Calibration results with monthly data from 2007 to 2009 indicate satisfactory daily streamflow validation by all strategies, except for S3, and the best results are also shown by S2. Daily streamflow validation for July to December of 2006, calibrated by S1 and S2 strategies, with monthly data from 2007 to 2009, is shown in Figure 6. The superior performance of S2 strategy over conventional calibration, on daily time step validation, may reflect its ability to reduce the parameter non-uniqueness problem, by defining parameter values that are more physically meaningful. Daily time step validation results are on Table 5.

Monthly streamflow validation for the year of 2006 shows high $\mathrm{p}$ and $\mathrm{r}$ factors for all strategies. According to Uda (2016), 2006 was a very dry year on the study area. This can be noticed on the precipitation and streamflow behavior during the year of 2006, on Figure 7. Monthly streamflow standard deviation for the year of 2006 is low, therefore, $r$-factor reaches high values for this particular year. The p-factor is acceptable (above 0.70) for the monthly streamflow validation of the 2006 year by strategies S1 and S2, and for the 2009 year by all strategies, except for S3.

Brighenti, Bonumá and Chaffe (2016) applied SWAT model to simulate the water cycle for the Negrinho river basin, which is a subbasin for the present study area. The authors calibrated and validated SWAT model on monthly and daily time steps and also reported difficulties to validate the year of 2006. For the mentioned study, SWAT was also calibrated and validated with SUFI-2, still, no $\mathrm{p}$ and $\mathrm{r}$ factors were reported.

The $r$-factor for the analyzed strategies indicate no uncertainty reduction on multi-variable calibration. In order to look for the best possible evapotranspiration simulation, values outside the initial range $(+/-0.25)$ for the relative parameters (CN2, SOL_AWC, SOL_K) were accepted on the second iteration. This extrapolation outside the initial ranges can be the cause for the increase on $\mathrm{r}$-factor values for multi-variable calibration strategies. A more deepened analysis of parameters and respective calibrated intervals, similar to the normalization carried out by Rajib, Merwade and $\mathrm{Yu}$ (2016), may lead to more information about the uncertainties related to each calibration strategy.

The evapotranspiration simulation performance is unsatisfactory for all strategies, both on calibration and validation periods. High PBIAS values for evapotranspiration on all periods and strategies may suggest that the model is unable to satisfactory simulate the actual evapotranspiration for the study area. Rajib, Merwade and Yu (2016) also reported low performance for the soil moisture simulation by SWAT model, even when measured soil moisture data were used to calibrate the model.

\section{Best_Par versus Range_Par}

The SUFI-2 calibration process indicates the best parameter set (Best_Par) and the calibrated interval values (Range_Par) for each parameter, in each iteration. The best parameter set values, when used to validate the model, have led to unsatisfactory model performance for several time intervals. Figure 8 and Figure 9 compare the results obtained using the best parameter set values (Best_Par) versus the parameter interval values (Range_Par), for monthly and daily streamflow.

It must be emphasized that according to Abbaspour, Johnson and Van Genuchten (2004) SUFI-2 should not be used to define a single set of parameter values, but to define an adequate interval value for each calibrated parameter.

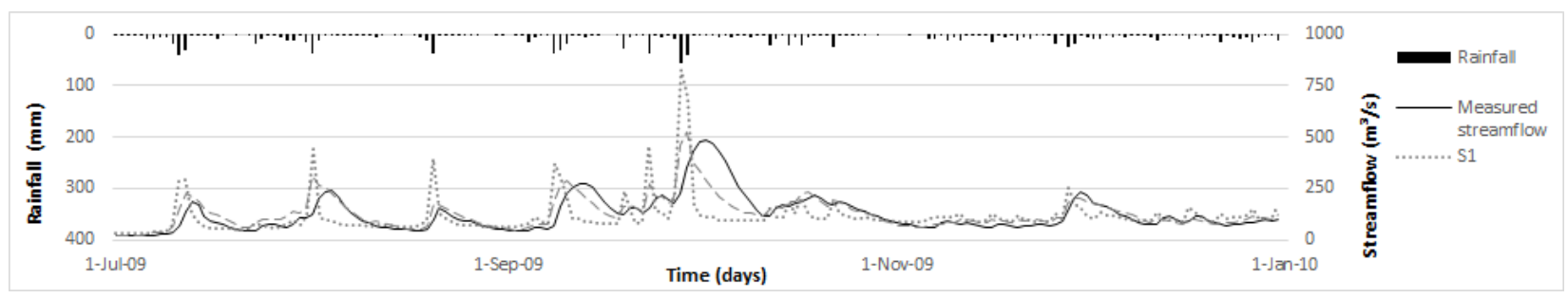

Figure 5. Daily streamflow from 01 July to 31 December of 2009, calibrated with monthly data from 2006 to 2008.

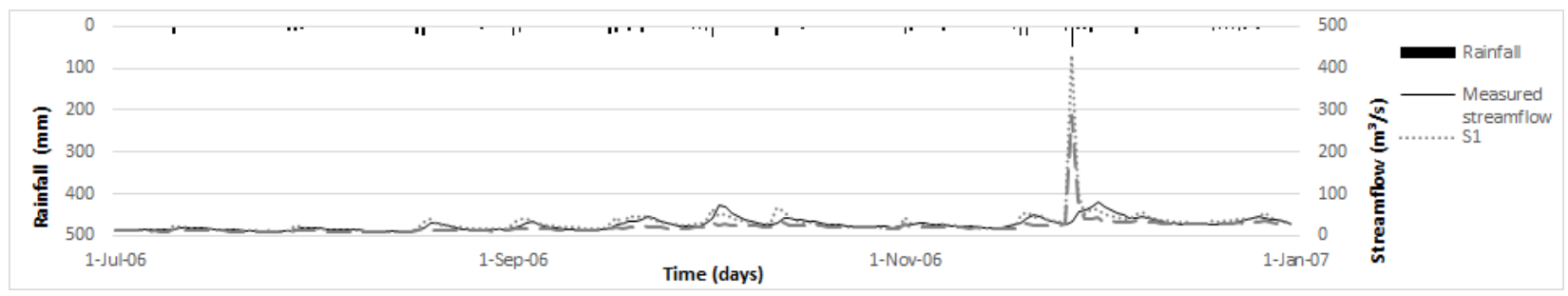

Figure 6. Daily streamflow from 01 July to 31 December of 2006, calibrated with monthly data from 2007 to 2009. 


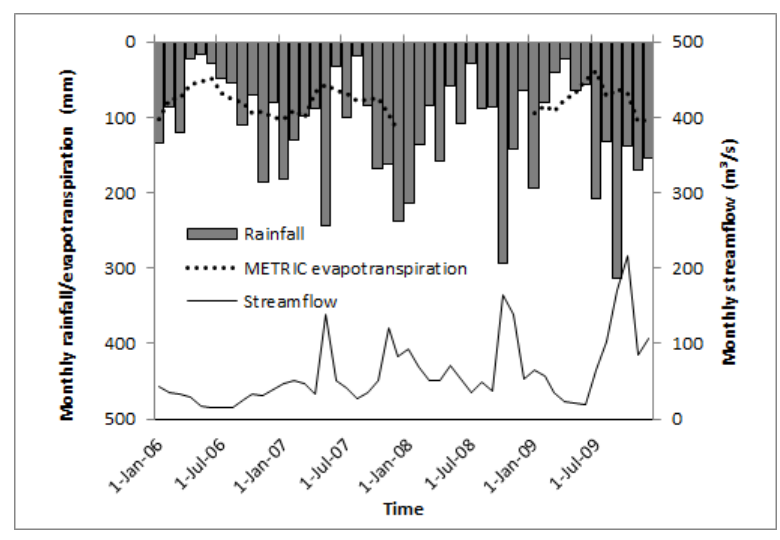

Figure 7. Average monthly rainfall and streamflow.

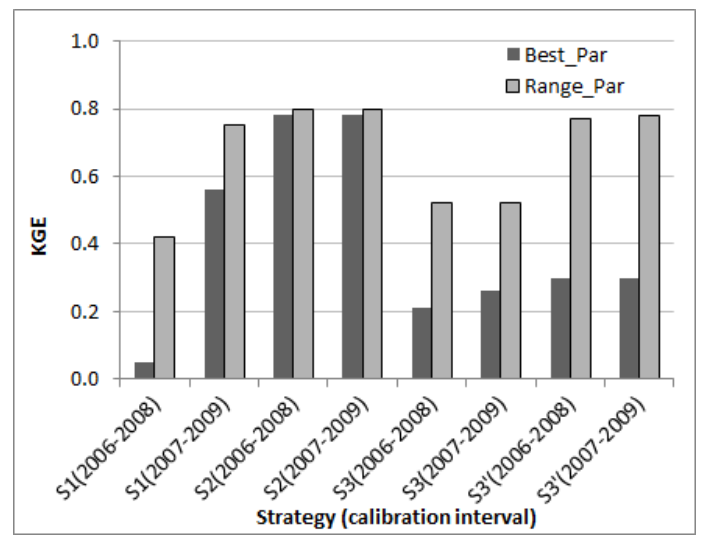

Figure 8. Daily streamflow performance (KGE) for the entire simulation interval, using parameter values interval (Range_Par) and best parameter set (Best_Par).

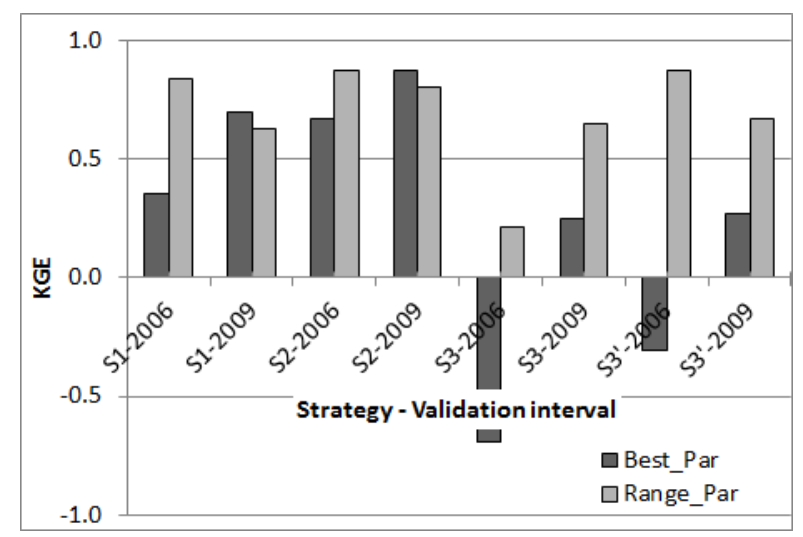

Figure 9. Monthly streamflow performance (KGE) for the entire simulation interval, using parameter values interval (Range_Par) and best parameter set (Best_Par).

\section{CONCLUSIONS}

The present study analyzed different calibration strategies, including the conventional calibration using streamflow data only, and multi-variable calibration with evapotranspiration data. The results led to the following conclusions:
- Multi-variable calibration (evapotranspiration + streamflow) did not presented uncertainty reduction ( $r$-factor) on streamflow model prediction. A more deepened analysis of parameters and respective calibrated intervals may lead to more information about the uncertainties of each calibrated strategy;

- Multi-variable calibration (evapotranspiration + streamflow) streamflow performance was superior to the other strategies for monthly and daily time steps;

- After the first iteration of the calibration using solely evapotranspiration (S3' strategy), model performance was satisfactory. But after the second iteration ( $\mathrm{S} 3$ strategy) model performance was unsatisfactory, with worse streamflow simulation performance compared to S3'. Model calibration using only evapotranspiration still requires more studies.

Further studies regarding the use of different remote sensing products, such as soil moisture, are encouraged. The use of multiple streamflow stations for model calibration and validation are also suggested. Uncertainty analysis regarding model parameters and other output variables are also promising alternatives for the deepened understanding of uncertainty.

\section{ACKNOWLEDGEMENTS}

Authors thank CNPq and UFSC, for the financial support for the research activities, and the hydrology laboratory-UFSC, for the support. Authors also thank EPAGRI, COPEL and INMET for the data, kindly provided for this study.

\section{REFERENCES}

ABBASPOUR, K. C. Calibration of hydrologic models: when is a model calibrated? In: INTERNATIONAL CONGRESS ON MODELLING AND SIMULATION (MODSIM2015), 21., Australia. Proceedings... New Zealand: Modelling and Simulation Society of Australia, 2005. p. 2449-2455.

ABBASPOUR, K. C. SWAT-CUP: SWAT calibration and uncertainty programs-a user manual. Eawag: Swiss Federal Institute of Aquatic Science and Technology, 2015.

ABBASPOUR, K. C.; JOHNSON, C. A.; VAN GENUCHTEN, M. T. Estimating uncertain flow and transport parameters using a sequential uncertainty fitting procedure. Vadose Zone Journal, v. 3, n. 4, p. 1340, 2004. http://dx.doi.org/10.2136/vzj2004.1340.

ABBOT'T, M. B.; REFSGAARD, J. C. Distributed hydrological modelling. Dordrecht: Springer Netherlands, 1996. v. 22.

ALLEN, R. G.; TASUMI, M.; MORSE, A.; TREZZA, R.; WRIGHT, J. L.; BASTIAANSSEN, W.; KRAMBER, W.; LORITE, I.; ROBISON, C. W. Satellite-based energy balance for Mapping Evapotranspiration with Internalized Calibration (METRIC)applications. Journal of Irrigation and Drainage Engineering, v. 133, 
n. 4, p. 395-406, 2007. http://dx.doi.org/10.1061/(ASCE)07339437(2007)133:4(395).

ANA - AGÊNCIA NACIONAL DE ÁGUAS. Brasília: ANA, 2016. Available from: < hidroweb.ana.gov.br>. Access on: 28 june 2016.

ARNOLD, J. G.; MORIASI, D. N.; GASSMAN, P. W.; ABBASPOUR, K. C.; WHITE, M. J.; SRINIVASAN, R.; SANTHI, C.; HARMEL, R. D.; VAN GRIENSVEN, A.; VANLIEW, M. W.; KANNAN, N.; JHA, M. K. Swat: model use, calibration, and validation. Transactions of the ASABE, v. 55, n. 4, p. 1491-1508, 2012. http:/ / dx.doi.org/10.13031/2013.42256.

BASTIAANSSEN, W. G. M.; ALLEN, R. G.; PEREIRA, L. S.; SMITH, M.; RAES, D.; WRIGHT, J. L. SEBAL model with remotely sensed data to improve water-resources management under actual field conditions. Journal of Irrigation and Drainage Engineering, v. 131, p. 2, 2005.

BEVEN, K. A manifesto for the equifinality thesis. Journal of Hydrology, v. 320, n. 1-2, p. 18-36, 2006. http://dx.doi.org/10.1016/j. jhydrol.2005.07.007.

BEVEN, K. Rainfall-runoff modelling: the primer. 2nd ed. Chichester: Lancaster University, 2012.

BEVEN, K.; BINLEY, A. The future of distributed models: model calibration and uncertainty prediction. Hydrological Processes, v. 6, n. 3, p. 279-298, 1992. http://dx.doi.org/10.1002/hyp.3360060305.

BEVEN, K. J. Prophecy, reality and uncertainty in distributed hydrological modelling. Advances in Water Resources, v. 16, n. 1, p. 41-51, 1993. http://dx.doi.org/10.1016/0309-1708(93)90028-E.

BRESSIANI, D. A.; GASSMAN, P. W.; FERNANDES, J. G.; GARBOSSA, L. H. P.; SRINIVASAN, R.; BONUMÁ, N. B.; MENDIONDO, E. M. A review of soil and water assessment tool (SWAT) applications in Brazil: challenges and prospects. International Journal of Agricultural and Biological Engineering, v. 8, n. 3, p. 1-27, 2015.

BRIGHENTI, T. M.; BONUMÁ, N. B.; CHAFFE, P. L. B. Calibração hierárquica do modelo swat em uma bacia hidrográfica Catarinense. Revista Brasileira de Recursos Hídricos, v. 21, n. 1, p. 53-64, 2016. http://dx.doi.org/10.21168/rbrh.v21n1.p53-64.

DAGGUPATI, P.; PAI, N.; ALE, S.; DOUGLAS-MANKIN, K. R.; ZECKOSKI, R. W.; JEONG, J.; PARAJULI, P. B.; SARASWAT, D.; YOUSSEF, M. A. A recommended calibration and validation strategy for hydrologic and water quality models. Transactions of the ASABE, v. 58, n. 6, p. 1705-1719, 2015a. http://dx.doi. org/10.13031/trans.58.10712.

DAGGUPATI, P.; YEN, H.; WHITE, M. J.; SRINIVASAN, R.; ARNOLD, J. G.; KEITZER, C. S.; SOWA, S. P. Impact of model development, calibration and validation decisions on hydrological simulations in West Lake Erie Basin. Hydrological Processes, v. 29, n. 26, p. 5307-5320, 2015b. http://dx.doi.org/10.1002/hyp.10536.
EMBRAPA - EMPRESA BRASILEIRA DE PESQUISA AGROPECUÁRIA. Brasil em relevo. Brasília: EMBRAPA, $2016 \mathrm{a}$. Available from: <http://www.relevobr.cnpm.embrapa.br>. Access on: 28 june 2016.

EMBRAPA - EMPRESA BRASILEIRA DE PESQUISA AGROPECUÁRIA. GeoPortal. Brasília: EMBRAPA, 2016b. Available from: <http://mapoteca.cnps.embrapa.br>. Access on: 28 june 2016.

EMBRAPA - EMPRESA BRASILEIRA DE PESQUISA AGROPECUÁRIA. Sistema de informação de solos. Brasília: EMBRAPA, 2016c. Available from: <https://www.bdsolos.cnptia.embrapa. br>. Access on: 28 june 2016.

FASOLO, P. J.; POTTER, R. O.; DE CARVALHO, A. P.; FLORES, C. A.; BOGNOLA, I.; POTTER, R. O.; RAUEN, M. J.; CARDOSO, A.; DE CARVALHO, A. P.; HOCHMULLER, D. P.; RIBAS, G. C.; RACHWAL, M. F.; GUIMARÃES, S.; SANTOS, H. G.; AGLIO, M. L. D.; CHAFFIN, C. E.; SOUZA, J. S. Levantamento de reconbecimento de solos do estado de Santa Catarina. Embrapa Solos, 2004.

FRANCO, A. C. L.; UDA, P. K.; QUEEN, G.; BERNARDI, N. Aplicação do método de balanço hídrico sazonal na bacia do alto rio Negro. In: SIMPÓSIO BRASILEIRO DE RECURSOS HÍDRICOS, 21., 2015. Anais... Brasília: ABRH, 2015.

GITHUI, F.; SELLE, B.; THAYALAKUMARAN, T. Recharge estimation using remotely sensed evapotranspiration in an irrigated catchment in southeast Australia. Hydrological Processes, v. 26, n. 9 , p. 1379-1389, 2012. http://dx.doi.org/10.1002/hyp.8274.

GREEN, C.; VANGRIENSVEN, A. Autocalibration in hydrologic modeling: Using SWAT2005 in small-scale watersheds. Environmental Modelling \& Software, v. 23, n. 4, p. 422-434, 2008. http://dx.doi. org/10.1016/j.envsoft.2007.06.002.

GUPTA, H. V.; KLING, H.; YILMAZ, K. K.; MARTINEZ, G. F. Decomposition of the mean squared error and NSE performance criteria: implications for improving hydrological modelling. Journal of Hydrology, v. 377, n. 1-2, p. 80-91, 2009. http://dx.doi. org/10.1016/j.jhydrol.2009.08.003.

HER, Y.; CHAUBEY, I. Impact of the numbers of observations and calibration parameters on equifinality, model performance, and output and parameter uncertainty. Hydrological Processes, v. 29, n. 19, p. 4220-4237, 2015. http://dx.doi.org/10.1002/hyp.10487.

IMMERZEEL, W. W.; DROOGERS, P. Calibration of a distributed hydrological model based on satellite evapotranspiration. Journal of Hydrology, v. 349, n. 3-4, p. 411-424, 2008. http://dx.doi. org/10.1016/j.jhydrol.2007.11.017.

KLEMEŠ, V. Operational testing of hydrological simulation models. Hydrological Sciences Journal, v. 31, n. 1, p. 13-24, 1986. http://dx.doi.org/10.1080/02626668609491024. 
KUNNATH-POOVAKKA, A.; RYU, D.; RENZULLO, L. J.; GEORGE, B. The efficacy of calibrating hydrologic model using remotely sensed evapotranspiration and soil moisture for streamflow prediction. Journal of Hydrology, v. 535, p. 509-524, 2016. http:/ / dx.doi.org/10.1016/j.jhydrol.2016.02.018.

MENESES, P. R.; ALMEIDA, T. Introdução ao processamento de imagem de sensoriamento remoto. Brasília: CNPQ/Unb, 2012.

MIRANDA, E. E. Brasil em relevo. Campinas: Embrapa Monitoramento por Satélite, 2005.

MORADKHANI, H.; SOROOSHIAN, S. General review of rainfall-runoff modeling: model calibration, data assimilation, and uncertainty analysis. In: SOROOSHIAN, S.; HSU, K. L.; COPPOLA, E.; TOMASSETTI, B.; VERDECCHIA, M.; VISCONTI, G. Hydrological modelling and the water cycle. Heidelberg: Springer Berlin Heidelberg, 2009. p. 1-24. v. 63.

MORIASI, D. N.; ARNOLD, J. G.; VAN LIEW, M. W.; BINGER, R. L.; HARMEL, R. D.; VEITH, T. L. Model evaluation guidelines for systematic quantification of accuracy in watershed simulations. Transactions of the ASABE, v. 50, n. 3, p. 885-900, 2007. http:// dx.doi.org/10.13031/2013.23153.

MUTHUWATTA, L. A. L. P.; BOOIJ, M. J.; RIENTJES, T. O. M. H. M. Calibration of a semi-distributed hydrological model using discharge and remote sensing data. In: YILMAZ, K.; YUCEL, I.; GUPTA, H. V.; WAGENER, T.; YANG, D.; SAVENIJE, H.; NEALE, C.; KUNSTMANN, H.; POMEROY, J. (Eds.). New Approaches to Hydrological Prediction in Data-sparse Regions. Wallingford: IAHS Press, 2009. p. 52-58.

NEITSCH, S. L.; ARNOLD, J. G.; KINIRY, J. R.; WILLIAMS, J. R. SWAT: model use, calibration, and validation. Texas: Texas A\&M University System, 2011.

RAJIB, M. A.; MERWADE, V.; YU, Z. Multi-objective calibration of a hydrologic model using spatially distributed remotely sensed/ in-situ soil moisture. Journal of Hydrology, v. 536, p. 192-207, 2016. http://dx.doi.org/10.1016/j.jhydrol.2016.02.037.

SANTOS, H. G. D.; CARVALHO JUNIOR, W. D.; DART, R. D. O.; ÁGLIO, M. L. D.; SOUSA, J. D. S.; PARES, J. G.; FONTANA, A.; MARTINS, A. L. D. S.; OLIVEIRA, A. P. Mapa de solos do Brasil. Brasília: Embrapa Solos, 2011.

SANTOS, R. D. O.; SCUDELARI, A. C.; RIGHETTO, A. Avaliação da produção e aporte de sedimentos para o Rio Potengi, RN. Revista Brasileira de Recursos Hidricos, v. 18, n. 3, p. 149-163, 2013. http://dx.doi.org/10.21168/rbrh.v18n3.p149-163.
STRAUCH, M.; LIMA, J. E. F. W.; VOLK, M.; LORZ, C.; MAKESCHIN, F. The impact of Best Management Practices on simulated streamflow and sediment load in a Central Brazilian catchment. Journal of Environmental Management, v. 127, p. S24-S36, 2013. Supplement. PMid:23422359. http://dx.doi.org/10.1016/j. jenvman.2013.01.014.

THOMÉ, V. M. R.; ZAMPIERI, S.; BRAGA, H. J.; PANDOLFO, C.; SILVA JÚNIOR, V. P. DA; BACIC, I.; LAUS NETO, J.; SOLDATELI, D.; GEBLER, E.; ORE, J. D.; ECHEVERRIA, L.; MATTOS, M.; SUSKI, P. P. Zoneamento Agroecológico e Socioeconômico do Estado de Santa Catarina. Santa Catarina: EPAGRI, 1999.

UDA, P. K. Evapotranspiração real da bacia do rio Iguaçu por meio do modelo METRIC. 2016. 179 f. Tese (Doutorado em Engenharia Ambiental) - Universidade Federal de Santa Catarina, Florianópolis, 2016.

WAGENER, T.; GUPTA, H. V. Model identification for hydrological forecasting under uncertainty. Stochastic Environmental Research and Risk. Assessment, v. 19, n. 6, p. 378-387, 2005. http://dx.doi. org/10.1007/s00477-005-0006-5.

WANDERS, N.; BIERKENS, M. F. P.; DE JONG, S. M.; DE ROO, A.; KARSSENBERG, D. The benefits of using remotely sensed soil moisture in parameter identification of large-scale hydrological models. Water Resources Research, v. 50, n. 8, p. $6874-$ 6891, 2014. http://dx.doi.org/10.1002/2013WR014639.

YANG, J.; REICHERT, P.; ABBASPOUR, K. C.; XIA, J.; YANG, H. Comparing uncertainty analysis techniques for a SWAT application to the Chaohe Basin in China. Journal of Hydrology, v. 358, n. 1-2, p. 1-23, 2008. http://dx.doi.org/10.1016/j.jhydrol.2008.05.012.

YAPO, P. O.; GUPTA, H. V.; SOROOSHIAN, S. Multi-objective global optimization for hydrologic models. Journal of Hydrology, v. 204, n. 1-4, p. 83-97, 1998. http://dx.doi.org/10.1016/S00221694(97)00107-8.

ZHANG, Y.; CHIEW, F. H. S.; ZHANG, L.; LI, H. Use of remotely sensed actual evapotranspiration to improve rainfall-runoff modeling in Southeast Australia. Journal of Hydrometeorology, v. 10, n. 4, p. 969-980, 2009. http://dx.doi.org/10.1175/2009JHM1061.1.

\section{Authors contributions}

Ana Clara Lazzari Franco: Paper conception, data analysis, simulations, literature review, discussion, paper writing.

Nadia Bernardi Bonumá: Paper writing and discussion. 